\title{
CARDIAC OUTPUT IN RELATION TO UNILATERAL PNEUMOTHORAX IN MAN
}

\author{
BY ANDRÉ COURNAND, NATALIE A. BRYAN AND DICKINSON W. RICHARDS, JR. \\ (From the Department of Medicine, College of Physicians and Surgeons, Presbyterian \\ Hospital, and the Tuberculosis Service, Bellevue Hospital, New York City)
}

(Received for publication September 24, 1934)

The effects upon cardiac output of the establishment of a closed unilateral pneumothorax have been investigated from time to time in animals for many years past; but in man only very recently. The animal experimentation has had varying results, depending upon the type of experiment performed and the species of animal used $(1,5,8)$. Most of them have been acute experiments, in which there has thus been no close similarity with the gradually induced and chronically maintained therapeutic pneumothorax. After a review of the literature, Weiss (1) concluded that in animals (such as rabbits) with imperforate mediastinum, the usual effect of unilateral pneumothorax is a decrease in total cardiac output, though he considered this to be due to secondary pulmonary and circulatory effects rather than to the pneumothorax itself. Perhaps the nearest morphological analogy have been the recent experiments of Hilton (2) on goats, a species whose mediastinum is apparently similar to that of man. Using animals of 20 to $25 \mathrm{kgm}$. weight, he found that a small pneumothorax $(200 \mathrm{cc}$.) caused a small increase in cardiac output, associated with decrease in arterial oxygen saturation. A large pneumothorax ( $500 \mathrm{cc}$.) caused a fall in cardiac output, with further fall in oxygen saturation.

The first report that we have found of cardiac output measurements in man following the establishment of unilateral pneumothorax is that of Berconsky in 1931 (3). His method was essentially that of Field, Bock, Gildea and Lathrop (4), using $\mathrm{CO}_{2}$ tensions of the alveolar air as equivalent to $\mathrm{CO}_{2}$ tension of the arterial blood, and using the rebreathing technique to establish mixed venous $\mathrm{CO}_{2}$ tensions. $\mathrm{He}$ made three measurements on one case and one on a second; both were young women with nearly complete collapse of one lung. The three values for cardiac output in the first case averaged about 3.2 liters per minute, or less than half the average value obtained by this method with normal subjects. In the one determination on the second case, the cardiac output was 7.4 liters per minute, or near the upper limit of his values for normal women. The method in this study provided no proof that alveolar air was equivalent to arterial blood in respect to $\mathrm{CO}_{2}$ tension, or that a definite equilibrium with respect to $\mathrm{CO}_{2}$ tension had been reached by rebreathing, in the technique for determining $\mathrm{CO}_{2}$ tensions of oxygenated mixed venous blood.

Richards, Riley and Hiscock (5) published in 1932 the results of determinations of cardiac output, also using a method involving the Fick principle, on three young men, before and at intervals during the establishment of unilateral pneumothorax. In one of these cases standard basal conditions were not maintained, and alveolar air samples only were used to determine values of arterial $\mathrm{CO}_{2}$ tension. The experiments on the other two cases were more carefully controlled. Standard basal conditions were observed. Arterial $\mathrm{CO}_{2}$ content was measured directly as well as indirectly through the use of $\mathrm{CO}_{2}$ tensions of alveolar air; in one case in every determination except one of the experiments in the control period, in the other case once during the control period and twice during the period when pneumothorax was being induced. In the determination of $\mathrm{CO}_{2}$ tensions of the oxygenated mixed venous blood, an equilibrium was established in successive rebreathing procedures, according to a technique previously described by Richards and Strauss (6) (also reviewed in the preceding paper by the present authors (7)). In one of the two patients, who had one lung approximately 50 per cent collapsed in one week, there occurred a diminution in cardiac output from an average of 5.0 liters per minute to an average of 3.3 liters per minute. The second case, one of whose lungs was about 70 per cent collapsed in a month, had a cardiac output at the end of this period of 4.0 liters per minute, as 
compared with an average figure of 4.8 liters per minute in the control period.

During the past year Nylin (8) has published the results of cardiac output determinations on two carefully studied cases, before and during the course of establishment of unilateral pneumothorax. For the cardiac output determinations the acetylene method of Grollman was used. The first case was a man of 32 , with a right lower lobe lesion. Practically complete collapse of the lung was obtained, with intrapleural pressure about neutral. Cardiac output varied between 4.6 and 3.7 liters per minute, but there was no consistent change after collapse of the lung was established. The second case was a woman with extensive tuberculosis of the left lung. Collapse was obtained in this case also, though high positive pleural pressures $(+7,+9$ and +12 , +14 ) were maintained. In this case also there was no consistent change in cardiac output following pneumothorax, the values varying between 3.6 and 3.0 liters per minute.

The discrepancy in the results of the two papers just referred to calls for both examination of the technique employed and further study of the same subject. The method of Richards, Riley and Hiscock (5), even with the greatest care observed, involves a considerable experimental error, as further studies to be reported presently will show. An average decrease in cardiac output of 34 per cent in the first of the two cases and 17 per cent in the second would seem, however, to be outside these limits of error. When pneumothorax is established, as we will also show presently, $\mathrm{CO}_{2}$ tension of the alveolar air cannot be relied upon to represent the $\mathrm{CO}_{2}$ tension of the arterial blood; in the second case of Richards, et al., therefore, more numerous arterial blood studies should have been done. Since both of the cases had apparently normal pulmonary function, except for pneumothorax, it seems likely that the method of obtaining mixed venous tensions was adequate, if one may judge from the results of the previous paper by the present authors (7). However, as no studies were made of the $\mathrm{CO}_{2}$ and oxygen tensions of arterial blood drawn during the rebreathing procedure, this point remains unproved.

Nylin's use of the acetylene method raises the question of adequate mixture of this foreign gas through the lung fields in cases of pneumo- thorax. No proof is presented that this took place, and it is of course an essential feature for proper application of the method (16). The recent studies of Björkman (9) show that collapsed lungs vary considerably in the amount by which they are aerated by respiratory movements.

In the present investigation we have made determinations of cardiac output on six cases with unilateral pneumothorax. Short case histories are given at the end of the paper. There were three cases of tuberculosis followed before and during pneumothorax treatment; one patient with healing lung abscess who was studied while she had a partial pneumothorax and again after complete re-expansion; and two patients with spontaneous pneumothorax, with at first strongly positive pleural pressures, on whom measurements were made at various stages of collapse. All the patients were afebrile throughout the periods of study.

\section{METHOD}

The technique was similar to that employed by Richards, Riley and Hiscock (5) but with more extended study of each individual case, and particular efforts to establish the validity of the arterial and venous $\mathrm{CO}_{2}$ values, upon which this cardiac output measurement is based.

Standard basal conditions were observed, the patient moving only from the ward to the laboratory in the morning, then resting for half an hour or longer on the bed. The patient lay in the supine position, with one pillow. Mouthpiece and noseclip were applied and he breathed through the apparatus for ten minutes in order that a steady state might be reached. A diagram of the apparatus used is shown in Figure 1 of our preceding paper (7). A six-minute sample of expired air was first collected in the spirometer. Then at the end of a normal expiration, at a signal "blow," a complete expiration was made by the subject, while slide valve $B$ was shut off. At the end of complete expiration a sample of alveolar air was taken into one of the evacuated sampling tubes, and the slide valve then reopened. After a rest period of from three to five minutes the alveolar sampling was repeated; this time, immediately after the taking of the alveolar sample, valve $E$ was turned to connect with the rebreathing bag. The subject then emptied and filled the bag with successive deep respirations, at the rate usually of one every 5 seconds, sometimes slightly more rapidly. In the early experiments a sample, at the end of a complete expiration, was taken into an evacuated tube after 15 seconds' rebreathing, then another respiration made, and valve $E$ turned, closing off the rebreathing bag; a sample ( 20 seconds) was then taken from the bag. In the later experiments more evacuated sampling tubes were attached, and samples at the end of expiration were taken 15,20,25 and 30 seconds after the beginning of 
rebreathing. The subject then had a rest period of 15 to 30 minutes after which the whole procedure just described was repeated.

Arterial blood samples $(20 \mathrm{cc}$.) were drawn, while the subject respired through the apparatus, after infiltration with novocaine of the region of the brachial artery. With some subjects this was done before the rebreathing procedures, with others after, with others between the two periods. There appeared to be no difference, in this respect, in results obtained. There was no evidence that the puncture disturbed the steady state of the individual.

Gas analyses were done with the Haldane apparatus.

Special precautions were taken in handling the blood. It was drawn into an oiled syringe, transferred, under parafin oil, to chilled bottles containing dried potassium oxalate and sodium fluoride, as described in our preceding paper. The blood was kept on ice until the analyses were done. Duplicate analyses of $\mathrm{CO}_{2}$ and $\mathrm{O}_{2}$ content were made, and, according to the "first method" of Austin, Van Slyke, et al. (11), two points were determined on the oxygenated whole blood $\mathrm{CO}_{2}$ curve. The tensions of the points were about $35 \mathrm{~mm}$. and $55 \mathrm{~mm}$. The curve was drawn on logarithmic paper, by the use of the linear relationship of Peters (18).

On this $\mathrm{CO}_{2}$ diagram, arterial, alveolar, and mixed venous points were then plotted, arteriovenous differences obtained, and cardiac output calculated in the usual manner by dividing arteriovenous $\mathrm{CO}_{2}$ difference into $\mathrm{CO}_{2}$ output per minute, and dividing this quotient by 10 , to give cardiac output in liters. It was thought that arterial blood represented mixed venous blood in respect to water and electrolyte contents, more closely than would any peripheral venous sample.

In addition to the measurements incident to the determination of cardiac output, rebreathing experiments to determine mixed venous $\mathrm{CO}_{2}$ tensions were carried out from time to time during each patient's course, to insure so far as possible the applicability of the method. These have been described in our preceding paper (7). It will be noted that four of the subjects of the present investigation also had particular studies made of their mixed venous equilibria.

\section{CRITICISM OF METHOD}

Against cardiac output methods of the type described above, two general criticisms are usually made, and with justification. The first is that the various technical manipulations with blood and alveolar gases are so many, and the resulting arteriovenous difference of $\mathrm{CO}_{2}$ content so small that even with the most scrupulous technique the error of method will be large. We have discussed this in the preceding paper, in connection with determination of venous $\mathrm{CO}_{2}$ values, and concluded that this error will be at least 10 per cent, when one includes both the level of the $\mathrm{CO}_{2}$ dissociation curve, and the mixed venous tensions.

The second criticism concerns the additional error that occurs in the determination of arterial $\mathrm{CO}_{2}$ content. Even when an arterial puncture is painless, there may be, as Jansen, Knipping and Stromberger (12) and others have shown, irregularities of pulse or respiration that may disturb the subject's steady state and so change the arterial $\mathrm{CO}_{2}$ level from its resting value. Work by numerous investigators has, however, shown that the $\mathrm{CO}_{2}$ tension of alveolar air and of arterial blood obtained during the same resting period, with trained subjects, are in agreement (13). This applies to average results; it is quite true that in individual experiments there may be differences of a millimeter or more. It is also true that with certain individuals a technique such as the Haldane-Priestley will give $\mathrm{CO}_{2}$ tensions of alveolar air that consistently differ by a millimeter or more from those of the arterial blood (14).

In cases of abnormal pulmonary function it is of course not justifiable to assume that $\mathrm{CO}_{2}$ tensions of alveolar air and arterial blood will correspond; in our tables we have included figures for cardiac output based upon arterial blood values only, except in control periods when no pneumothorax existed.

It should be noted also that since we do not know whether or not the acid-base relations of extravascular blood (oxalated or heparinized) exactly correspond with those of intravascular blood, arteriovenous differences as calculated have probably more of a relative than absolute significance.

From the above it is probably fair to conclude that in the use of this method repeated measurements in a given state are necessary, that to be significant one group of measurements should differ from another by well over 10 per cent, perhaps as much as 20 per cent.

It is far from an ideal technique, as it has a large error and is laborious and difficult. Its advantage in these cases of pulmonary abnormality is that by it one can obtain an indication in any given case whether the method is applicable or not.

Our interest in the present paper lies in the changes in cardiac output occurring in a given subject rather than in the absolute values of this function. Which of the various methods for cardiac 
TABLE I

Cardiac output and other circulatory and respiratory functions in relation to unilateral pneumothorax.

\begin{tabular}{|c|c|c|c|c|c|c|c|c|c|c|c|c|c|c|c|c|c|c|c|}
\hline \multirow{2}{*}{$\begin{array}{c}\text { Patient, } \\
\text { sex, age } \\
\text { and } \\
\text { height }\end{array}$} & \multirow[b]{2}{*}{ Date } & \multirow[b]{2}{*}{ Wt. } & \multirow{2}{*}{$\begin{array}{l}\text { Pul- } \\
\text { mon- } \\
\text { ary } \\
\text { ven- } \\
\text { tila- } \\
\text { tion }\end{array}$} & \multirow{2}{*}{$\begin{array}{l}\mathrm{CO}_{2} \\
\text { out- } \\
\text { put }\end{array}$} & \multirow{2}{*}{$\begin{array}{c}\mathrm{O}_{2} \\
\text { in- } \\
\text { take }\end{array}$} & \multicolumn{3}{|c|}{ Arterial blood } & \multirow{2}{*}{$\begin{array}{l}\mathrm{Al}- \\
\text { veo- } \\
\text { lar } \\
\mathrm{CO}_{2}\end{array}$} & \multirow{2}{*}{\multicolumn{2}{|c|}{$\begin{array}{l}\text { Oxygen- } \\
\text { ated ven- } \\
\text { ous } \mathrm{CO}_{2}\end{array}$}} & \multicolumn{2}{|c|}{$\underset{\text { difference }}{\mathrm{A}-\mathrm{V} \mathrm{CO}_{2}}$} & \multicolumn{2}{|c|}{$\begin{array}{l}\text { Cardiac } \\
\text { output }\end{array}$} & \multirow{2}{*}{$\begin{array}{c}\text { Vital } \\
\text { ca- } \\
\text { pac- } \\
\text { ity }\end{array}$} & \multirow{2}{*}{\begin{tabular}{|c} 
Ven- \\
ous \\
pres- \\
sure
\end{tabular}} & \multirow{2}{*}{$\begin{array}{c}\text { Pleural } \\
\text { pressure }\end{array}$} & \multirow{2}{*}{$\begin{array}{l}\text { Lung } \\
\text { col- } \\
\text { lapse }\end{array}$} \\
\hline & & & & & & & & & & & & & & & & & & & \\
\hline & & kgm. & $\begin{array}{c}\text { liters } \\
\text { per } \\
\text { min- } \\
\text { ute }\end{array}$ & $\begin{array}{c}c c . \\
\text { per } \\
\text { min- } \\
\text { ute }\end{array}$ & $\begin{array}{c}c c . \\
\text { per } \\
\text { min- } \\
\text { ute }\end{array}$ & $\begin{array}{c}\text { vol- } \\
\text { umes } \\
\text { per } \\
\text { cent }\end{array}$ & $\begin{array}{c}\text { vol- } \\
\text { umes } \\
\text { per } \\
\text { cent }\end{array}$ & $\begin{array}{l}\text { per } \\
\text { cent }\end{array}$ & $m m$. & $\mathbf{m m}$. & $\begin{array}{c}\text { ool- } \\
\text { umes } \\
\text { per } \\
\text { cent }\end{array}$ & \begin{tabular}{|c} 
vol- \\
umes \\
per \\
cent
\end{tabular} & $\begin{array}{c}\text { vol- } \\
\text { umes } \\
\text { per } \\
\text { cent }\end{array} \mid$ & $\begin{array}{c}\text { liters } \\
\text { per } \\
\text { min- } \\
\text { ute }\end{array}$ & $\begin{array}{c}\text { liters } \\
\text { per } \\
\text { min- } \\
\text { ute }\end{array}$ & liters & $\mathrm{mm}$. & $\mathrm{cm}$. & $\begin{array}{l}\text { per } \\
\text { cent }\end{array}$ \\
\hline $\begin{array}{l}\text { E. S. } \\
\text { male } \\
17 \\
\text { height } \\
183 \mathrm{~cm} .\end{array}$ & $\begin{array}{l}\text { June } 10 \\
\text { June } 15 \\
\text { June } 29 \\
\text { July } 12 \\
\text { Aug. } 5 \\
\text { Sept. } 21\end{array}$ & $\begin{array}{l}93 \\
86 \\
86\end{array}$ & $\begin{array}{l}7.73 \\
7.28 \\
7.20 \\
7.99 \\
8.57 \\
7.20\end{array}$ & $\begin{array}{l}256 \\
243 \\
243 \\
219 \\
224 \\
217\end{array}$ & $\begin{array}{l}323 \\
301 \\
315 \\
277 \\
318 \\
296\end{array}$ & \begin{tabular}{|l|}
49.6 \\
51.7 \\
47.2 \\
49.4 \\
51.9
\end{tabular} & $\begin{array}{l}\frac{20.2}{20.1} \\
20.1 \\
16.6 \\
18.8\end{array}$ & $\begin{array}{l}97 \\
95 \\
96 \\
93 \\
98\end{array}$ & $\begin{array}{l}39.3 \\
39.1 \\
39.9 \\
35.4 \\
34.1 \\
36.4\end{array}$ & $\begin{array}{l}49.1 \\
49.9 \\
48.7 \\
46.9 \\
48.0 \\
47.4\end{array}$ & \begin{tabular}{|l|}
53.4 \\
53.7 \\
54.5 \\
52.0 \\
54.4 \\
57.2
\end{tabular} & $\begin{array}{l}3.8 \\
2.8 \\
4.8 \\
5.0 \\
5.3\end{array}$ & $\begin{array}{l}4.1 \\
4.5 \\
3.7 \\
5.5 \\
6.4 \\
4.9\end{array}$ & $\begin{array}{l}6.7 \\
8.7 \\
4.6 \\
4.5 \\
4.1\end{array}$ & \begin{tabular}{|l|}
6.2 \\
5.4 \\
6.6
\end{tabular} & $\begin{array}{l}\bar{z} \\
\bar{z} \\
\overline{-}\end{array}$ & $\begin{array}{l}\overline{7} \\
60 \\
90 \\
95\end{array}$ & $\begin{array}{r}-3,-8 \\
+5,-1 \\
+12,+4\end{array}$ & $\begin{array}{r}0 \\
0 \\
0 \\
20 \\
70 \\
85\end{array}$ \\
\hline $\begin{array}{l}\text { M. P. } \\
\text { female } \\
22 \\
\text { height } \\
142 \mathrm{~cm} .\end{array}$ & $\begin{array}{ll}\text { Jan. } & 27 \\
\text { Jan. } & 31 \\
\text { Feb. } & 25 \\
\text { Mar. } 9\end{array}$ & 50 & $\begin{array}{l}5.68 \\
5.37 \\
5.19 \\
4.98\end{array}$ & $\begin{array}{l}163 \\
144 \\
156 \\
155\end{array}$ & $\begin{array}{l}203 \\
183 \\
204 \\
199\end{array}$ & $\begin{array}{l}42.4 \\
42.4 \\
46.0\end{array}$ & $\begin{array}{l}17.9 \\
18.9 \\
18.8\end{array}$ & $\begin{array}{l}91 \\
98 \\
97\end{array}$ & $\begin{array}{l}32.7 \\
33.7 \\
36.8 \\
35.4\end{array}$ & $\begin{array}{l}42.3 \\
42.4 \\
43.4 \\
42.5\end{array}$ & $\begin{array}{l}47.0 \\
47.1 \\
49.6 \\
49.1\end{array}$ & $\begin{array}{l}4.6 \\
4.7 \\
3.6 \\
-\end{array}$ & $\begin{array}{l}4.2 \\
4.0 \\
3.3 \\
3.5\end{array}$ & $\begin{array}{l}3.5 \\
3.1 \\
4.3\end{array}$ & $\begin{array}{l}4.7 \\
4.4\end{array}$ & $\overline{1.3}$ & $\begin{array}{l}80 \\
=\end{array}$ & $\begin{array}{l}-1,-6 \\
+1,-6 \\
-4,-12 \\
-2,-10\end{array}$ & $\begin{array}{r}40 \\
60 \\
0 \\
0\end{array}$ \\
\hline $\begin{array}{l}\text { D. J. } \\
\text { male } \\
20 \\
\text { height } \\
178 \mathrm{~cm} .\end{array}$ & $\begin{array}{ll}\text { Apr. } & 18 \\
\text { Apr. } & 22 \\
\text { May } 24 \\
\text { June } 3\end{array}$ & 67.3 & $\begin{array}{l}6.49 \\
6.29 \\
6.61 \\
7.00\end{array}$ & $\begin{array}{l}214 \\
195 \\
206 \\
195\end{array}$ & $\begin{array}{l}238 \\
223 \\
262 \\
247\end{array}$ & $\begin{array}{l}50.8 \\
50.2 \\
48.6 \\
43.9\end{array}$ & $\begin{array}{l}18.5 \\
18.8 \\
18.3 \\
18.3\end{array}$ & $\begin{array}{l}96 \\
95 \\
92 \\
94\end{array}$ & $\begin{array}{l}37.9 \\
39.1 \\
34.8 \\
32.3\end{array}$ & $\begin{array}{l}49.7 \\
49.7 \\
48.7 \\
45.6\end{array}$ & $\begin{array}{l}55.2 \\
54.0 \\
52.6 \\
48.7\end{array}$ & $\begin{array}{l}4.4 \\
3.8 \\
4.0 \\
4.8\end{array}$ & $\begin{array}{l}4.5 \\
4.3 \\
6.1 \\
6.4\end{array}$ & $\begin{array}{l}4.9 \\
5.1 \\
5.1 \\
4.1\end{array}$ & $\begin{array}{l}4.8 \\
4.5\end{array}$ & $\begin{array}{l}\frac{4.1}{3.1} \\
2.9\end{array}$ & $\begin{array}{r}\overline{60} \\
30 \\
125\end{array}$ & $\begin{array}{l}+1,-1 \\
+3,-2\end{array}$ & $\begin{array}{r}0 \\
0 \\
30 \\
40\end{array}$ \\
\hline $\begin{array}{l}\text { F. P. } \\
\text { male } \\
26 \\
\text { height } \\
180 \mathrm{~cm} .\end{array}$ & $\begin{array}{l}\text { Mar. } 25 \\
\text { Mar. } 30 \\
\text { Apr. } 5 \\
\text { Apr. } 11 \\
\text { Apr. } 27 \\
\text { May } 11 \\
\text { June } 7 \\
\text { June } 22 \\
\text { July } 30 \\
\text { Oct. } 11\end{array}$ & \begin{tabular}{|l|}
59.6 \\
60.6 \\
61.9 \\
63.2 \\
62.3 \\
59.6
\end{tabular} & $\begin{array}{l}6.17 \\
6.80 \\
6.79 \\
6.71 \\
7.04 \\
6.84 \\
6.56 \\
6.72 \\
6.90 \\
7.55\end{array}$ & $\begin{array}{l}166 \\
213 \\
201 \\
206 \\
197 \\
196 \\
180 \\
195 \\
177 \\
199\end{array}$ & $\begin{array}{l}199 \\
255 \\
235 \\
241 \\
236 \\
236 \\
230 \\
250 \\
230 \\
263\end{array}$ & $\begin{array}{l}\bar{Z} \\
\overline{54.2} \\
54.2 \\
51.1 \\
50.0 \\
49.7 \\
50.4 \\
48.2 \\
49.5\end{array}$ & $\begin{array}{l}\bar{z} \\
17.6 \\
17.7 \\
16.8 \\
17.0 \\
18.3 \\
18.4 \\
18.7 \\
17.3\end{array}$ & $\begin{array}{l}\bar{Z} \\
94 \\
93 \\
90 \\
93 \\
95 \\
93 \\
94\end{array}$ & $\begin{array}{l}42.0 \\
41.1 \\
42.4 \\
41.7 \\
36.5 \\
36.3 \\
36.6 \\
35.6 \\
34.0 \\
35.5\end{array}$ & $\begin{array}{l}51.4 \\
53.6 \\
53.4 \\
51.9 \\
48.1 \\
48.3 \\
49.1 \\
50.4 \\
48.1 \\
49.3\end{array}$ & $\begin{array}{l}57.6 \\
58.5 \\
57.5 \\
57.9 \\
55.6 \\
54.7 \\
53.3 \\
50.9 \\
52.5 \\
54.0\end{array}$ & $\begin{array}{l}\overline{-} \\
3.3 \\
3.7 \\
4.5 \\
4.7 \\
3.6 \\
4.5 \\
4.3 \\
4.5\end{array}$ & $\begin{array}{l}3.7 \\
4.9 \\
4.4 \\
4.1 \\
4.9 \\
5.0 \\
5.9 \\
6.6 \\
6.3 \\
5.8\end{array}$ & $\begin{array}{l}- \\
6.1 \\
5.6 \\
4.4 \\
4.2 \\
5.0 \\
4.3 \\
4.1 \\
4.4\end{array}$ & $\begin{array}{l}4.5 \\
4.4 \\
4.6 \\
5.0\end{array}$ & $\begin{array}{l}\frac{4.5}{Z} \\
4.5 \\
3.0 \\
2.4 \\
2.8 \\
\frac{2.2}{2}\end{array}$ & $\begin{array}{l}25 \\
\bar{Z} \\
26 \\
42 \\
70 \\
50 \\
50\end{array}$ & $\begin{array}{r}0,-4 \\
-1,-4 \\
+5,+1 \\
+3,+1 \\
+3,-2 \\
0,-7\end{array}$ & $\begin{array}{r}0 \\
0 \\
0 \\
0 \\
40 \\
50\end{array}$ \\
\hline $\begin{array}{l}\text { I. A. } \\
\text { male } \\
24 \\
\text { height } \\
180 \mathrm{~cm} .\end{array}$ & $\begin{array}{ll}\text { Jan. } & 28 \\
\text { Feb. } & 1 \\
\text { Feb. } & 16 \\
\text { Mar. } 3 \\
\text { Mar. } 14\end{array}$ & 62.0 & $\begin{array}{l}6.53 \\
5.98 \\
5.47 \\
4.85 \\
5.00\end{array}$ & $\begin{array}{l}175 \\
182 \\
166 \\
171 \\
171\end{array}$ & $\begin{array}{l}208 \\
227 \\
190 \\
208 \\
216\end{array}$ & $\begin{array}{l}48.2 \\
49.9 \\
49.7 \\
50.1 \\
51.1\end{array}$ & $\begin{array}{r}22.0 \\
21.8 \\
22.8 \\
22.9 \\
22.9\end{array}$ & $\begin{array}{l}94 \\
93 \\
93 \\
96 \\
95\end{array}$ & $\begin{array}{l}35.3 \\
39.2 \\
39.2 \\
39.8 \\
40.3\end{array}$ & $\begin{array}{l}48.5 \\
51.3 \\
51.1 \\
50.2 \\
50.0\end{array}$ & \begin{tabular}{|l|}
52.6 \\
53.2 \\
52.8 \\
53.0 \\
54.3
\end{tabular} & $\begin{array}{l}4.4 \\
3.3 \\
3.1 \\
2.9 \\
3.2\end{array}$ & $\begin{array}{l}6.6 \\
5.2 \\
5.8 \\
5.1 \\
4.7\end{array}$ & $\begin{array}{l}4.0 \\
5.5 \\
5.5 \\
5.9 \\
5.3\end{array}$ & & $\begin{array}{l}\overline{1.5} \\
\overline{1.8} \\
2.0\end{array}$ & $\begin{array}{l}\frac{80}{85} \\
67 \\
-\end{array}$ & $\begin{array}{l}+8,+10 \\
+4,+10 \\
+5,-1\end{array}$ & $\begin{array}{l}85 \\
70 \\
85 \\
60 \\
35\end{array}$ \\
\hline $\begin{array}{l}\text { L. P. } \\
\text { male } \\
29 \\
\text { height } \\
188 \mathrm{~cm} .\end{array}$ & $\begin{array}{l}\text { Mar. } 6 \\
\text { Mar. } 10 \\
\text { Mar. } 28 \\
\text { Apr. } 14 \\
\text { Apr. } 25 \\
\text { May } 18\end{array}$ & $\begin{array}{l}61.0 \\
62.9 \\
64.1 \\
65.6 \\
70.0\end{array}$ & $\begin{array}{l}6.00 \\
5.41 \\
6.32 \\
5.90 \\
5.54 \\
5.79\end{array}$ & $\begin{array}{l}215 \\
207 \\
212 \\
205 \\
210 \\
222\end{array}$ & $\begin{array}{l}259 \\
244 \\
260 \\
292 \\
256 \\
239\end{array}$ & $\begin{array}{l}46.9 \\
48.1 \\
47.7 \\
47.0 \\
48.5 \\
49.7\end{array}$ & $\begin{array}{l}20.5 \\
20.9 \\
20.9 \\
20.0 \\
21.4 \\
21.2\end{array}$ & $\begin{array}{l}95 \\
95 \\
93 \\
93 \\
98 \\
99\end{array}$ & $\begin{array}{l}38.5 \\
40.4 \\
38.9 \\
38.9 \\
38.8 \\
36.1\end{array}$ & $\begin{array}{l}48.2 \\
47.1 \\
45.7 \\
46.8 \\
46.4 \\
46.6\end{array}$ & $\begin{array}{l}51.6 \\
52.3 \\
51.7 \\
53.3 \\
52.0 \\
53.6\end{array}$ & $\begin{array}{l}4.7 \\
4.2 \\
4.0 \\
6.3 \\
3.5 \\
3.9\end{array}$ & $\begin{array}{l}3.9 \\
2.7 \\
2.9 \\
3.2 \\
3.6 \\
4.7\end{array}$ & $\begin{array}{l}4.6 \\
4.9 \\
5.3 \\
3.3 \\
6.0 \\
5.7\end{array}$ & & $\begin{array}{l}2.1 \\
2.4 \\
1.7 \\
2.1 \\
2.6 \\
3.4\end{array}$ & $\begin{array}{r}105 \\
45 \\
78 \\
60 \\
67 \\
60\end{array}$ & $\begin{array}{r}+8,+1 \\
+4, \pm 2 \\
+10, \pm 3 \\
+8, \pm 1 \\
+6,-2\end{array}$ & $\begin{array}{l}80 \\
65 \\
85 \\
75 \\
65 \\
30\end{array}$ \\
\hline
\end{tabular}

output determination gives values nearest the actual true ones is difficult to say. Earlier Fickprinciple methods gave values in normal subjects that were almost certainly too high, due to inadequate technique for determining $\mathrm{CO}_{2}$ or oxygen of the mixed venous blood (6). Later Fickprinciple methods have given lower figures, in the region of 2.0 to 3.0 liters per minute per square meter of body surface (14). Starr's (15) recently published figures with a revised ethyl iodide inhalation technique are similar to these $(2.40 \pm .55$ liters $)$. The nitrous oxide method and the acetylene method have slightly lower normal values $(2.2 \pm .2$ liters for the latter). The comparisons of Bauman and Grollman (16) between figures obtained by use of the acetylene technique and those obtained by direct puncture of the right heart are valuable evidence, but were all apparently carried out on patients with some pathological condition. In four patients with presumably normal cardiac output this value varied between 2.2 and 3.3 liters per minute per square meter of body surface. Certain recent experiments with the acetylene technique suggest that this may give values that are too low: when for example, in a case of anemia Bandow, Birkner and Bohnenkamp (17) find arteriovenous oxygen differences that are 125 per cent of the subject's total oxygen capacity, one must necessarily question the reliability of the method in this instance. The most likely cause would seem to be recirculation of blood within the time of the experiment; Grollman himself (16) has carefully considered this possibility. 
RESULTS

The values for cardiac output in relation to pneumothorax and to several other circulatory and pulmonary functions determined at the same time for the six cases studied are given in Table $\mathrm{I}$. In Figure 1 ( $A, B$ and $C$ ) the values for cardiac output of each case, in liters per minute per square meter of body surface, are plotted against the degree of collapse of the lung.

It will be seen that in the two cases most care-
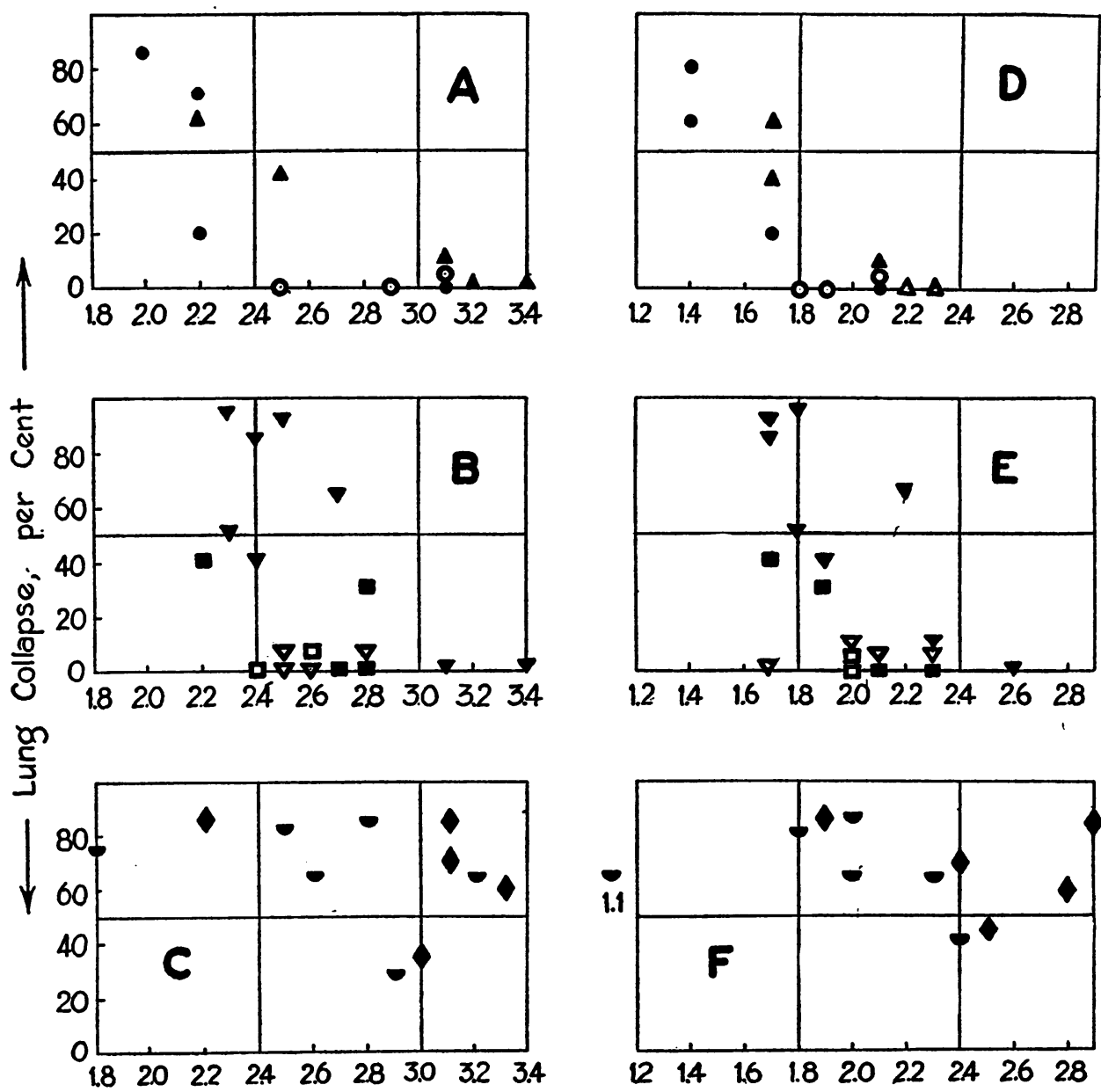

Cardiac Output (Liters per minute) per Sq. m. Body Surface
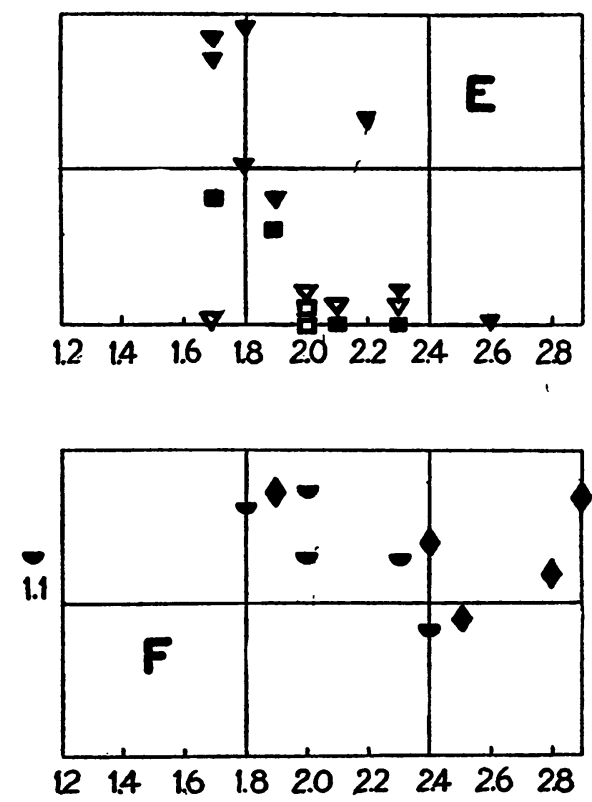

fully studied and most adequately controlled (cf. preceding paper), Table I and Figure 1 (A), there was an unmistakable decrease in cardiac output while the subject had pneumothorax, partial or complete. One case was studied first during pneumothorax and later after reexpansion, the other patient was first studied before establishing pneumothorax. There was a good deal of variation in values during the control period in the latter patient; one of the measurements based on

Fig. 1. Cardiac Output Relations in Pneumothorax.

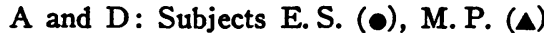
B and E: Subjects F. P. ( $)$, D. J. ( $(\boldsymbol{D})$
C and F: Subjects I. A. ( (), L. P. ( $(\bullet)$

Black symbols represent data calculated from arterial blood $\mathrm{CO}_{2}$ contents, open symbols data based on alveolar $\mathrm{CO}_{2}$ tensions. 
arterial blood $\mathrm{CO}_{2}$ content was improbably high, and has been omitted from Figure 1.

In the other two cases of therapeutic pneumothorax, F. P. and D. J., studies of the equilibrium between rebreathed air and simultaneously drawn arterial blood were not made (see previous paper (7)), but as the other criteria were satisfactory, and pulmonary function except for the pneumothorax was good, it was thought that the technique employed was applicable. The results are shown in Figure 1 (B). The average cardiac output in F. P. per unit of body surface after pneumothorax was 14 per cent less than the average in the control period; but the scattering and overlapping of the values were considerable, and one cannot hold this difference to be significant. With D. J. no consistent change was found. There appeared to be a decrease in the last experiment with one lung collapsed at 40 per cent; unfortunately this patient left the hospital before further data were obtained.

Starr et al. (15), have shown a better correlation between cardiac output and oxygen consumption than between cardiac output and body surface. We have plotted this relationship in Figure 1 (D, E and F). Expressed in this way, the relative decrease in cardiac output during pneumothorax is brought out more clearly; even with patients F. P. and D. J. there is little overlapping of values determined during the pneumothorax as compared with the control period.

The two cases of spontaneous pneumothorax, as shown in Figure 1 ( $C$ and $F$ ) showed a wide variation of cardiac output, and no relation to the extent of pneumothorax. As discussed in our previous paper (7), further investigation of the mixed venous equilibrium in these two cases cast some doubt on the applicability of the method.

\section{DISCUSSION}

In the control state without pneumothorax the cardiac outputs of the cases E. S. and M. P. were somewhat higher than the average which we find by this method in normal individuals; in Figure 2 (A), for example, the average control value was 3.0 liters, that in Figure 2 (B) was 2.8 liters, which is about that usually obtained by this method in this age group. For subject E. S., the high control value is probably accounted for by
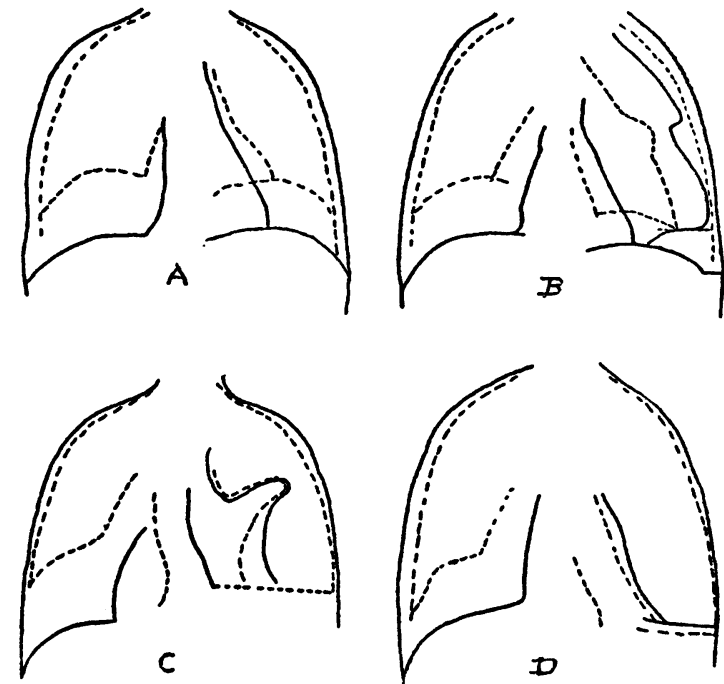

Fig. 2. X-ray Outlines of Subject E. S. During Deep Inspiration (Continuous Lines) and Deep EXpiration (Dotted Lines), Showing Progressive EstabLISHMENT OF PNEUMOTHORAX.

A, June 29th; B, July 13th; C, August 4th; D, September 20th, 1932.

his age; Starr and his collaborators (15) have recently reported high values of cardiac output in the age group between 15 and 20 years. When expressed in terms of oxygen consumption per minute, it is found that all four of the cases of artificial pneumothorax had the same levels of cardiac output in the control periods (Figure 1, $\mathrm{D}$ and $\mathrm{E})$. Even though the values in Group A in the control periods were slightly high, the cardiac output in the presence of pneumothorax was lower than the normal limits by this method for this age group.

It seems unlikely that initial unfamiliarity on the part of the subjects with the technique was a significant factor in the higher values for cardiac output in the control periods. The subjects had been trained in the technique before any of the reported measurements were made. Furthermore, subject $M$. P. was, as noted, studied first in the state of pneumothorax, and later in the reexpanded state.

The mechanism of this particular circulatory adaptation is not apparent from the data which we have in these cases. There was no definite correlation with mediastinal displacement: M. P. had marked displacement; E. S. when his pneumothorax was complete showed almost none. 

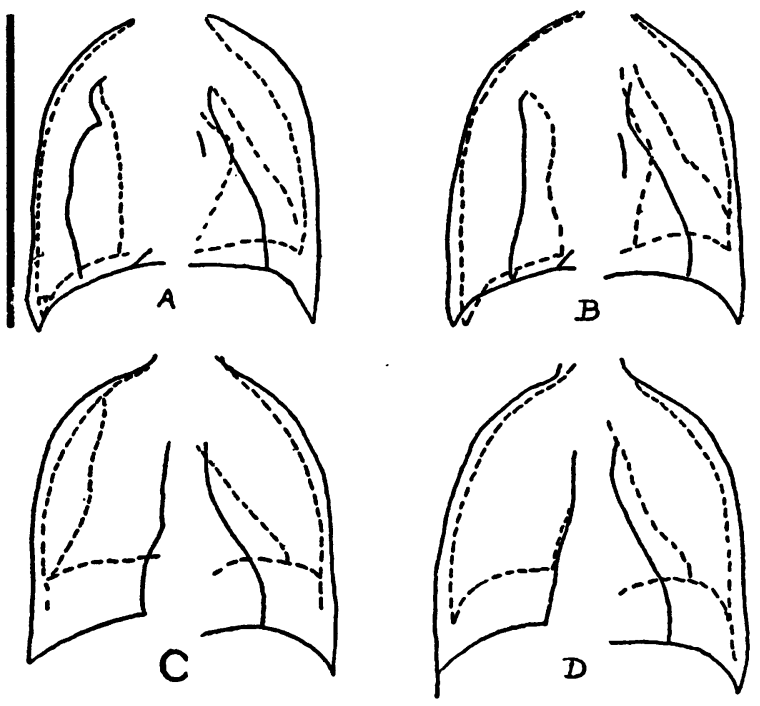

Fig. 3. X-RAy Outlines of Subject M. P.

Similar to Fig. 2. A, January 27th; B, January 31st; C, February 25th; D, March 9th, 1933.

(See Figures 2 and 3.) No consistent relation has been found with venous or pleural pressures, oxygen intake or chemical changes in the blood. Simple decrease in pulmonary vascular bed, as suggested by Richards, Riley and Hiscock, does not appear to be a determining factor. The only phenomenon observed that showed an apparent relation to decrease in cardiac output was the change in diaphragmatic movement produced by pneumothorax. The three cases whose cardiac output was decreased showed also either a greatly diminished or a paradoxical movement of the diaphragm on one side. The two cases of spontaneous pneumothorax and the fourth case (D. J.) of partial artificial pneumothorax had relatively little alteration in diaphragmatic excursion. Possibly pulmonary blood flow is related rather to the degree of ventilation of the collapsed lung than to the degree of collapse.

If one assembles all the cases thus far published in which the technique of measurement was probably adequate, one reaches the tentative inference that in simple unilateral pneumothorax there is a tendency to diminished cardiac output, which in individual cases may be marked, slight or absent. The situation may be not unlike the circulatory adaptation associated with change of posture in normal subjects, which shows similar differences in individual cases.

\section{SUM MARY}

1. Measurements of cardiac output have been made in six cases in various stages of unilateral pneumothorax. The method employed the Fick principle, arterial blood being drawn for arterial $\mathrm{CO}_{2}$, and oxygenated venous $\mathrm{CO}_{2}$ being obtained by a method described in the preceding paper.

2. In two cases of artificial pneumothorax cardiac output was definitely diminished when unilateral pneumothorax was established. In a third case there was a similar trend but not definitely beyond the error of the method. In one case of artificial pneumothorax, and in two cases of spontaneous pneumothorax with positive intrapleural pressures, no consistent relation between cardiac output and state of pneumothorax was demonstrated.

\section{BIBLIOGRAPHY}

1. Weiss, R., Uber die Durchblutung der Kollapslunge beim experimentellen Pneumothorax. Ztschr. f. d. ges. exper. Med., 1926, 53, 138.

2. Hilton, R., Some effects of artificial pneumothorax on the circulation. J. Path. and Bact., 1933, 37, 1.

3. Berconsky, I., El Volumen Circulatorio por Minuto. Imp. d. E. Spinelli, Buenos Aires, 1930.

4. Field, H., Bock, A. V., Gildea, E. F., and Lathrop, F. L., The rate of circulation of the blood in normal resting individuals. J. Clin. Invest., 1924, 1, 65.

5. Richards, D. W., Jr., Riley, C. B., and Hiscock, M., Cardiac output following artificial pneumothorax in man. Arch. Int. Med., 1932, 49, 994.

6. Richards, D. W., Jr., and Strauss, M. L., Carbon dioxide and oxygen tensions of the mixed venous blood of man at rest. J. Clin. Invest., 1930, 9, 475.

7. Richards, D. W., Jr., Cournand, A., and Bryan, N. A., Applicability of rebreathing method for determining mixed venous $\mathrm{CO}_{2}$ in cases of chronic pulmonary disease. J. Clin. Invest., 1935, 14, 173.

8. Nylin, G., Untersuchungen über das Minutenvolumen des Herzens in 2 Fällen mit einseitigem künstlichem Pneumothorax. Beitr. z. Klin. d. Tuberk., 1933, 83, 470.

9. Björkman, S., Bronchospirometrie. Acta med. Skandinav., 1934, suppl. 56.

10. Grollman, A., The effect of variation in posture on the output of the human heart. Am. J. Physiol., $1928,86,285$.

11. Austin, J. H., Cullen, G. E., Hastings, A. B., McLean, F. C., Peters, J. P., and Van Slyke, D. D., Studies of gas and electrolyte equilibria in blood. I. Technique for collection and analysis of blood and for its saturation with gas mixtures of known composition. J. Biol. Chem., 1922, 54, 121. 
12. Jansen, K., Knipping, H. W., and Stromberger, K., Klinische Untersuchungen über Atmung und Blutgase. Beitr. z. Klin. d. Tuberk., 1932, 80, 304.

13. Bock, A. V., Dill, D. B., Edwards, H. T., Henderson, L. J., and Talbott, J. H., On the partial pressures of oxygen and carbon dioxide in arterial blood and alveolar air. J. Physiol., 1929, 68, 277.

14. Burwell, C. S., and Robinson, G. C., A method for the determination of the amount of oxygen and carbon dioxide in the mixed venous blood of man. J. Clin. Invest., 1924, 1, 47;

Richards, D. W., Jr., and Strauss, M. L., Circulatory adjustment in anemia. J. Clin. Invest., 1928, 5, 161.

15. Starr, I., Jr., Donal, J. S., Margolies, A., Shaw, R., Collins, L. H., and Gamble, C. J., Studies of the heart and circulation in disease: Estimations of basal cardiac output, metabolism, heart size and blood pressure in 235 subjects. J. Clin. Invest., 1934, 13, 561.

16. Bauman, H., and Grollmann, A., Uber die theoretischen und praktischen Grundlagen und die klinische Zuverlässigkeit der Acetylenmethode zur Bestimmung des Minutenvolumens. Ztschr. f. klin. Med., 1930, 115, 41.

17. Bandow, F., Birkner, J., und Bohnenkamp, H., Zur Frage eines intrapulmonalen Sauerstoffverbrauchs bei Anämie. Deutsches Arch. f. klin. Med., 1933, 176, 178.

18. Peters, J. P., Eisenman, A. J., and Bulger, H. S., Studies of the carbon dioxide absorption curve of human blood. II. The nature of the curve representing the relation of $\mathrm{pH}$ to $\mathrm{BHCO}_{8}$. J. Biol. Chem., 1923, 55, 709.

\section{PROTOCOLS}

E. S., male, age 17, clerk, American. Admitted to Bellevue Hospital, September 4, 1931.

History-Tuberculosis found on routine $x$-ray. Family history: Sister had tuberculosis for five years.

Physical examination-Very well developed and well nourished. Few crackling râles between $2 \mathrm{~d}$ and $3 \mathrm{~d}$ interspaces on left.

$\mathrm{X}$-ray-Few nodular shadows at right apex and left hilum, and possibly small cavity in latter region.

Course-Rest cure for 6 months. After acute upper respiratory infection $\mathbf{x}$-ray showed increase in shadows on left with $3 \mathrm{~cm}$. cavity. Sputum then positive. Pneumothorax started July 5, 1932. On August 6th developed fever and chest fluid, fever lasting until mid-September. Sputum negative after August 18th. Mediastinum displaced before fluid developed, but fixed in mid position after fluid was absorbed. $\mathrm{Pa}$ tient discharged December 9, 1932.

M. P., female, age 22, clerk, American. Admitted to Bellevue Hospital, September 9, 1932.

History-Following ether anesthesia, patient developed, on August 11th, an abscess of the right upper lobe, characterized by severe sharp pain, followed by purulent foul sputum amounting to $2 \mathrm{oz}$. daily. At the time of admission the expectoration had increased to $4 \mathrm{oz}$.

Physical examination-Well nourished white female, not dyspneic; coughing moderately, expectoration about 4 oz., foul. Slight dulness over the right upper lobe posteriorly with very few coarse râles on coughing. No clubbing of the fingers. Rest of the examination negative.

$\mathrm{X}$-ray-Small cavity at the right apex.

Sputum-Negative for tubercle bacilli.

Course-Patient put on postural drainage; bronchoscoped on October 5th; expectoration gradually decreased to about $4 \mathrm{cc}$. and became mucoid in character and odorless. Artificial pneumothorax started November 16 th' to collapse the small residual cavity. Small refills were given twice weekly. On January 31, 1933 the biggest collapse was obtained, about 60 per cent with moderate displacement of the heart under neutral pressure. From that time on the lung was allowed to reexpand, cavity having disappeared. $\mathrm{Pa}$ tient was discharged on March 25th, the lung having fully reexpanded at that time; had no sputum, no cough.

D. J., age 20, salesman, Irish. Admitted to Bellevue Hospital, March 14, 1932.

History-Onset 12 months previous to admission with progressive lassitude and slight cough. Small hemoptyses at the beginning of March; practically no expectoration. Past history irrelevant. Family history: father died from tuberculosis.

Physical examination-Very slight cough, productive of very small amount of greenish sputum. Few crackling râles at the right apex; very good motion of the diaphragm on both sides and expansion of both halves of the chest.

$\mathrm{X}$-ray-Fibrotic change in the upper part of the right upper lobe with a cavity $3 \mathrm{~cm}$. in diameter. Rest of the film normal.

Sputum-Positive for tubercle bacilli on admission.

Course-Fever for first week after admission, none thereafter. Right pneumothorax started April 29th; refills then given twice a week. Good lung collapse with little mediastinal displacement. Sputum negative on May 20th. Patient left the hospital June 5, 1932.

F. P., male, age 26, waiter, Italian. Admitted to Bellevue Hospital, March 10, 1932.

History-Onset $11 \frac{1}{2}$ years previous to admission with loss of weight, 35 pounds, slight cough, increasing in past 6 months; pain in left chest. Stopped working the first of March. Past history, negative. Family history, negative.

Physical examination-Slightly emaciated; moderate cough and expectoration. Signs of small cavity in 
the left upper lobe; slight dulness, bronchial breathing and few crackling râles in the 1 st and $2 \mathrm{~d}$ interspaces anteriorly. Right lung apparently clear. Good motion of the diaphragm on both sides; symmetrical expansion of both halves of the chest. No dyspnea, no cyanosis.

$\mathrm{X}$-ray-Showed a cavity, $4 \mathrm{~cm}$. in diameter, located at the outer part of the left chest, at the 5th and 6th rib posteriorly and $2 \mathrm{~d}$ and $3 \mathrm{~d}$ rib anteriorly. Very slight nodular infiltration in the outer part of the right chest.

Sputum-Positive for tubercle bacilli.

Course-After 6 weeks of rest in bed, no improvement. Artificial pneumothorax was started on the left side on April 14th. Good collapse was obtained with progressive increase of pressure. Patient developed some fluid, almost from the start, which after May 10th did not show any tendency to increase. His mediastinum was displaced to the right with marked respiratory swing. Sputum negative on June 1st. Patient discharged August, 1932.

I. A., age 24, salesman, Puerto Rican. Admitted to Presbyterian Hospital, January 21, 1933.

History-Mild cough for 2 years. Chest $x$-ray 2 years previously was negative. Sudden onset of tightness in chest, 4 hours before admission, associated with dyspnea, pain in chest and palpitation.

Physical-Comfortable when at rest. Right side of chest immobile. Signs of large pneumothorax on right. Musical amphoric breath sounds heard over right chest. Temperature normal.

X-ray-90 per cent collapse of right lung. Considerable shift of mediastinum to left. Increased bronchial markings on left.

Sputum-Repeatedly negative. Vital capacity 1500 cc.
Venous pressure $80 \mathrm{~mm} . \mathrm{H}_{2} \mathrm{O}$. Pleural pressure +8 , $+10 \mathrm{~cm} . \mathrm{H}_{2} \mathrm{O}$.

Course-Slight reexpansion of lung in first week, then a second and even more complete collapse. Reexpansion proceeded steadily thereafter for the next 6 weeks, at which time it was practically complete and the patient was allowed to return home (March, 1933). He had been well except for recurrent upper respiratory infections, when heard from one year later.

L. P., age 29, salesman, Canadian. Admitted to Presbyterian Hospital, February 28, 1933.

History-Sudden onset of pain in right chest in February, 1933, followed by progressive dyspnea. Admitted to hospital 6 days later.

Physical examination-Right side of chest more expanded than left and immobile. Signs of large pneumothorax. Whistling amphoric breathing heard over right lower chest. Temperature normal.

$\mathrm{X}$-ray-85 per cent collapse of right lung. Moderate shift of mediastinum to left. Linear fibrosis in left upper lobe.

Sputum-Repeatedly negative. Vital capacity 1900 cc. Venous pressure $105 \mathrm{~mm} . \mathrm{H}_{2} \mathrm{O}$.

Course-Improvement with reexpansion of lung for 1 month. Vital capacity $2900 \mathrm{cc}$. Venous pressure 45 $\mathrm{mm} . \mathrm{H}_{2} \mathrm{O}$. Collapse of lung 40 per cent. Then a second spontaneous pneumothorax occurred, collapse of lung 85 per cent, vital capacity 1950 cc., venous pressure $78 \mathrm{~mm}$. $\mathrm{H}_{2} \mathrm{O}$, pleural pressure $+3,+10 \mathrm{~cm}$. $\mathrm{H}_{2} \mathrm{O}$. Condition unchanged for 2 weeks, after which re-expansion began and continued gradually. Discharged at the end of May with lung reexpansion nearly complete. Was well when heard from 4 months later. 